\title{
Immunoelectrophoretic investigations of blood serum proteins in muscular diseases
}

\author{
WALERIA ASKANAS \\ From the Department of Neurology, Medical Academy, Warsaw, Poland
}

In patients with various forms of muscular diseases some quantitative changes in serum protein fractions have been demonstrated with the aid of paper electrophoresis (Ionăşescu, Luca, Petrescu, and Călcaianu 1965; Löwenthal, Van Sande, and Karcher 1964; Niebrój-Dobosz and HausmanowaPetrusewicz, 1964; Oppenheimer and Milhorat, 1961). Most of the published work, based on experimental as well as clinical material, is concerned with analyses of muscle proteins, effects of denervation of muscle on these proteins (Stewart 1955) as well as their behaviour in dystrophic muscle (Engel, McFarlin, Drews, and Wochner 1966; Dreyfus and Schapira 1962; Keeler and Young, 1961). Reflection of the relevant phenomena in the serum has so far received little attention.

For a more detailed analysis of serum proteins in various forms of muscular disease we chose the method of immunoelectrophoresis, which is more informative with regard to particular fractions. Preliminary immunoelectrophoretic investigations, in which a specific diagnostic serum was used, showed in the behaviour of the serum $\beta_{1}$-globulins in patients with Duchenne's progressive muscular dystrophy certain changes (Askanas and Mazurczak, 1966). This called for comparisons of this behaviour with that of the serum protein fractions in patients with neurogenic muscular atrophy, and it also appeared interesting to see if the immunoelectrophoretic method would show changes in the protein pattern of the serum of carriers of Duchenne's progressive muscular dystrophy.

MATERIAL AND METHOD

Immunoelectrophoresis was used to investigate the sera of 36 patients with Duchenne's progressive muscular dystrophy, of 16 carrier mothers, and of 18 patients (Table I) with various forms of neurogenic muscular atrophy.

Diagnosis was based on typical clinical features, electromyography, histopathology of muscle specimens, and biochemical analyses. Sera of 20 young healthy subjects served as controls.

'The study is part of a research project supported by the N.I.H. Bethesda, U.S.A., under agreement no. 227702 with N.I.N.D.B.
TABLE I

SUMMARY OF CASES INVESTIGATED

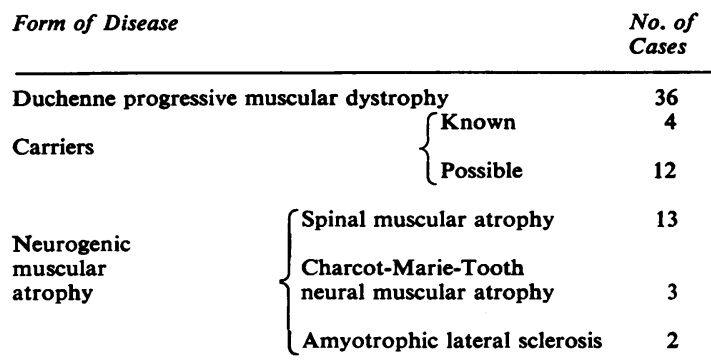

The total protein and protein fractions were determined in all the sera by paper electrophoresis.

Diagnostic sera of three kinds were used for immunoelectrophoresis, namely, rabbit antihuman serum $\left(\mathrm{AHS}_{\mathbf{R}}\right)$; rabbit anti-Duchenne serum $\left(\mathrm{ADS}_{R}\right)$ prepared by immunizing the animals with the mixed sera of patients with Duchenne's muscular dystrophy; and anti-WerdnigHoffman serum $\left(\mathrm{AWHS}_{\mathbf{R}}\right.$ ) prepared by immunizing rabbits with the mixed sera of patients with the WerdnigHoffman type of spinal muscular atrophy.

All the diagnostic sera were prepared in our own laboratory by immunizing rabbits as described earlier (Askanas and Mazurczak, 1966).

Immunoelectrophoresis was performed by Scheidegger's semi-micro method (Scheidegger, 1955), and after 24 hours of diffusion the preparations were photographed in transmitted light, washed several days in physiological saline, dried on paper, and stained for proteins with light green (Schwick, 1961), for fats with Sudan III (Schwick, 1961), and for both by combined staining (Grabar and Burtin, 1960).

In addition, sera of patients with Duchenne's progressive muscular dystrophy, carrier mothers, and healthy subjects were investigated by Ouchterlony's doublediffusion precipitation test in agar gel (Ouchterlony, 1953), the sera being used in dilutions of from $1: 2$ to $1: 128$. After 24 hours' diffusion the preparations were photographed in transmitted light, some of them washed, dried on paper, and stained for protein with light green.

\section{RESULTS}

In the sera of controls and carrier mothers the total 
protein and the behaviour of protein fractions did not depart from the normal. Neither were significant departures seen in the serum electropherograms of patients with Duchenne's progressive muscular dystrophy.

Paper electropherograms of the sera of 16 of the patients with neurogenic muscular atrophy showed in 13 a raised level of $\alpha_{2}$-globulins of 11.0 to $12.8 \%$ (normal in our laboratory between $6 \%$ and $10 \%$ ).

Immunoelectrophoresis with non-specific rabbit antihuman serum as the source of antibodies failed to demonstrate differences between the sick and the healthy controls in any of the cases considered.

When specific diagnostic sera were used the situation was different. With the serum $\mathrm{ADS}_{\mathrm{R}}$, an additional line in the zone of $\beta_{1}$-globulins was observed in $29(80.6 \%)$ of the 36 cases of Duchenne's progressive muscular dystrophy. A correlation between this immunoelectrophoretic abnormality and the clinical condition of the patients could not be established; this additional line was not seen in any of the control sera.

The same specific diagnostic serum, $\mathrm{ADS}_{\mathrm{F}}$, was used to investigate the sera of the 16 mothers of patients with Duchenne's progressive muscular dystrophy, and the additional line referred to above was obtained for $12(75 \%)$ whereas for the remaining four the pattern was normal.

The double diffusion precipitation test of Ouchterlony in which the serum $\mathbf{A H S}_{\mathbf{R}}$ was used failed to demonstrate differences between the sera of patients, mothers, and healthy controls.

With the serum $\mathrm{ADS}_{\mathbf{R}}$ as the source of antibodies, the sera of patients with Duchenne dystrophy and their mothers gave in Ouchterlony's test in $75 \%$ of the cases a larger number of precipitation lines than that in controls. This difference was most distinct with dilutions of $1: 16$ and $1: 32$.

Rabbit anti-Duchenne serum, ADS $_{R}$, was used in immunoelectrophoresis and the double-diffusion precipitation test to investigate the sera of six patients with limb-girdle and facio-scapulo-humeral dystrophy and of 10 with neurogenic muscular atrophy. In none of these cases were such abnormalities seen as those in patients with Duchenne progressive muscular dystrophy and their mothers.

When sera of patients with neurogenic muscular atrophy were investigated by immunoelectrophoresis with the specific rabbit anti-WerdnigHoffman serum $\left(A W H S_{R}\right)$, the number of precipitation lines in the zone of $\alpha_{2}$-globulins was in 16 cases larger than that seen in controls, but their distribution did not differ between patients with neural and those with spinal muscular atrophy.

Since the level of serum $\alpha_{2}$-globulins was found to be raised in patients with neurogenic muscular

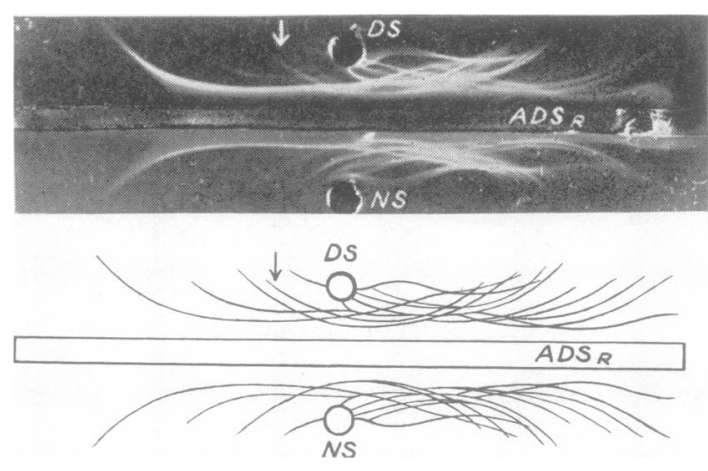

FIG. 1. $D S=$ Duchenne serum; $N S=$ normal serum; $A D S_{R}=$ rabbit anti-Duchenne serum. Arrow marks the additional line in the fraction of beta $a_{1}-$ globulins in the serum of the patient.
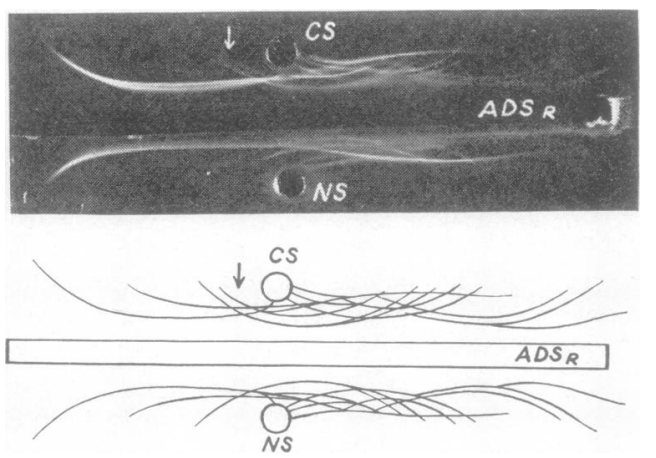

FIG. 2. $C S=$ carrier's serum; $N S=$ normal serum; $A D S_{R}=$ rabbit anti-Duchenne serum. Arrow marks the additional line in the zone of beta $a_{1}-$ globulins of the serum of carrier.
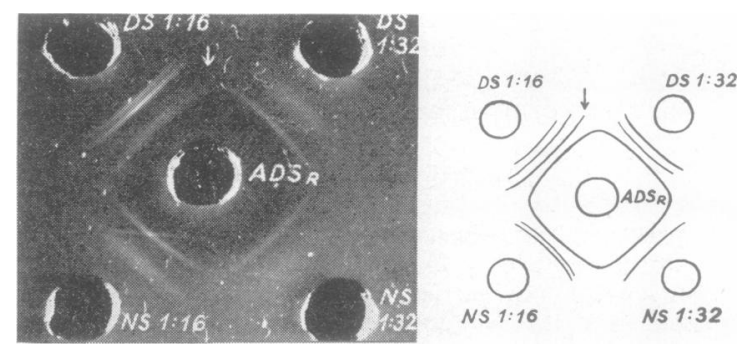

FIG. 3. Sera of patient and of control in the double diffusion precipitation test with the diagnostic serum $A D S_{R}$. In the middle well is $A D S_{R}$; in the upper, Duchenne serum in dilutions of $1: 16$ and $1: 32$; and in the bottom well, control serum. Arrow marks the difference between the sera as of the patient and control. 

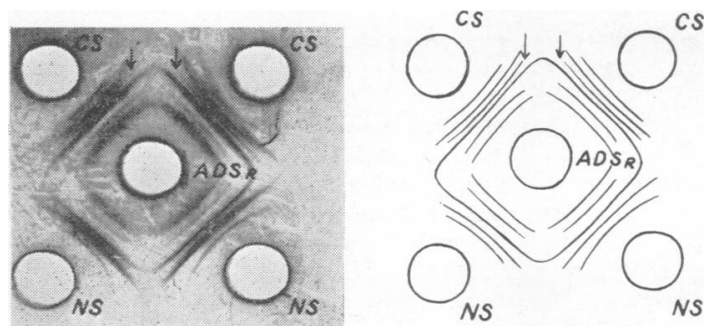

except one the immunoelectrophoretic pattern was the same for patients with Duchenne dystrophy and their healthy carrier mothers, hence the conclusion that the changes in the immunoelectrophoretic pattern are independent of the clinical manifestation of the disease. It appears that in sex-linked recessively heritable Duchenne dystrophy it is possible to register by the immunoelectrophoretic method a genetic protein defect, which is specific for this disease since it cannot be demonstrated in the other forms of dystrophy.

In neurogenic muscular atrophy, on the other hand, the raised level of $\alpha_{2}$-globulins corresponds to the larger number of precipitation arcs obtained in immunoelectrophoresis with the specific diagnostic serum AWHS $_{\mathbf{R}}$. That these changes are specific for neurogenic muscular atrophy is suggested by the fact that they are absent in patients with a raised level of $\alpha_{2}$-globulins due to other disease, or in patients with wasting of muscles in progressive muscular dystrophy. The abnormal serum protein pattern seen in patients with neurogenic muscular atrophy may well be supposed to be secondary to changes in the muscles. This also seems to be suggested by papers reporting reduction of protein in atrophying muscle (Sarteschi and Fabiani, 1958), which may conceivably lead to a rise of the level of one of the protein fractions in the serum.

In further studies now in progress in our lab-

FIG. 5. WHS = Werdnig-Hoffmann serum; $\quad N S=$ normal serum; $A W H S_{R}=$ rabbit anti-Werdnig-Hoffmann serum. Arrow shows the larger number of arcs in the zone of $\alpha_{2}$-globulins produced by the serum of patient. Photograph of preparation stained for proteins with light green.

atrophy, it became necessary to see whether the changes in the immunoelectrophoretic pattern did not depend upon this very fact. With this in view, the sera were examined of five persons whose levels of $\alpha_{2}$-globulins were raised in pneumonia, cardiac infarction, and rheumatic fever. Furthermore, $\mathrm{AWHS}_{\mathbf{R}}$ was used in 10 cases of Duchenne progressive muscular dystrophy. In none of these immunoelectropherograms were the abnormalities seen that are shown in cases of neurogenic muscular atrophy.

\section{DISCUSSION}

Analysis of the above material shows that the sera of patients with Duchenne progressive muscular dystrophy and their mothers, as well as of patients with neurogenic muscular atrophy, show changes in protein fractions that are demonstrable by immunoelectrophoresis only when specific diagnostic sera are used.

A large majority of patients with Duchenne dystrophy show characteristic changes in $\beta_{1}$-globulins, and so do most of the carriers. In all cases oratory the purpose is to identify these additional lines as well as the corresponding proteins.

SUMMARY

In Duchenne progressive muscular dystrophy immunoelectrophoresis revealed a genetic protein abnormality in the form of changes in the fraction of $\beta_{1}$-globulins, which is demonstrable in the serum of most of the patients and their mothers.

The changes in the protein pattern were registered only when specific diagnostic serum was used in the procedure.

In patients with neurogenic muscular atrophy changes in the fraction of $\alpha_{2}$-globulins, which may possibly depend on atrophy of the muscle, could be demonstrated in the serum but only when specific diagnostic serum was used ${ }^{\mathbf{1}}$.

\section{REFERENCES}

Askanas, W., and Mazurczak J. (1966). The serum immunoelectrophoretic test in patients with Duchenne's progressive muscular dystrophy. Preliminary report. Life Sciences, 5, 247-251.

${ }^{1}$ After the present paper had been written the additional line in the immunoelectropherograms of patients with Duchenne progressive muscular dystrophy and their mothers was found to correspond to haemopexin (Askanas, H. (1966), Life Sciences, 5, 1767-1773). 
Engel, W. K., McFarlin, D. E., Drews, G. A., and Wochner, R. D. (1966). Protein abnormalities in neuromuscular diseases. Part 2. J. Amer. med. Ass. 195, 837-842.

Dreyfus, J. C., and Schapira, G. (1962). Biochemistry of Hereditary myopathies. Thomas, Springfield, Illinois, pp. 36-37.

Grabar, P., and Burtin, P. (1960). Analyse immuno-électrophorétique. Masson, Paris.

Ionăşescu, V., Luca, N., Petrescu, A., and Călcaianu, G. (1965). Hereditary proximal spinal muscular atrophy. Biochemical investigations. Confin. neu-ol. (Basel) 25, 79-86.

Keeler, R. F., and Young, S. (1961). An electrophoretic analysis of protein extracts from normal and dystrophic ovine muscle. Biochem. J., 81, 93-98.

Löwenthal, A., Van Sande, M., and Karcher, D. (1964). Protéinogrammes et enzymogrammes des protéins musculaires en pathologie humaine. Clin. chim. Acta, 9, 31-39.

Niebrój-Dobosz, I., and Hausmanowa-Petrusewicz, I. (1964). Protein, lipoprotein and glycoprotein fractions of blood serum in muscle diseases. Pol. med. J., 3, 689-697.
Oppenheimer, H., and Milhorat, A. T. (1961). Serum proteins, lipoproteins, and glycoproteins in muscular dystrophy and related diseases. Ann. N.Y. Acad. Sci., 94, 308-319.

Ouchterlony, O. (1953). Antigen-antibody reactions in gels. Acta path. microbiol. scand., 32, 231-240.

Sarteschi, P., and Fabiani, P. (1958). L'indagine eletroforetica su carta delle proteine muscolari in alcune forme di distrofia muscolare e di atrofia muscolare progressiva neurale. Boll. Soc. med.-chir. Pisa., 26, 187-195.

Schwick, G. (1961). In Moderne Chemische Methoden in der Klinik by M. Buchner, pp. 532-561. Thieme, Leipzig.

Scheidegger, J. J. (1955). Une micro-méthode de l'immuno-électrophorèse. Int. Arch. Allergy, 7, 103-110.

Stewart, D. M. (1955). Changes in the protein composition of muscles of the rat in hypertrophy and atrophy. Biochem. J., 59, 553-558. 